\title{
九州におけるブュ科の種類相と分布について
}

\author{
呙岡考行* J. O. Ochoa** 山本進***

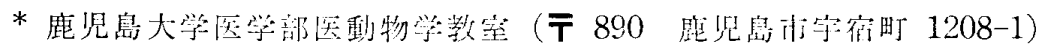 \\ **グァテマラ其和国淂生省マラリア䇏

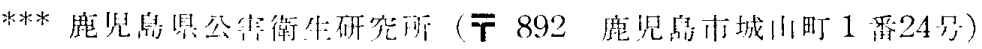

\section{(受储：1977㣙：5 月2311)}

Notes on the fauna and distribution of black-flies in Kyushu, Japan (Simuliidae ; Diptera)

Hiroyuki TAKAOKA,* J. O. OCHOA** and Susumu YAMAMOTO***

* Department of Medical Zoology, Faculty of Medicine, Kagoshima University, Usuki-cho, Kagoshima 890, Japan

** Servicio Nacional de Erradicacion de Malaria, de la Direccion General de Salud, 5 ave., 11-40, Zona 11, Guatemala, Guatemala

*** Kagoshima Prefectoral Institute of Envirommental Pollution and Public Health, Shiroyama-cho, Kagoshima 892, Japan

九州のブュ (Simuliidae)に関しては Shiraki(1935), Ogata and Sasa (1954), [Bentinck] (1955) および緒方 ら（1956）の調査報告があり，佐賀県を除く各県下をあ わせて 2 属19種類の分布が明らかにされた。 その後，九 州地域でのブュに関する調查はほとんど行われていな い．今回九州全域においてブユの分布の実態を把握する 目的で九州各罢下に扔いて採集調查を行い，既知分布種 に加え数種の九州産未記録種を得るなどの新知見を得た ので報告する。

\section{調査地区および方法}

\section{1. 調查地区}

採集は下記の12地区の144籄所に㧈いて行った。図 1 に各調查地区の概略を示した。

1. 英彦山山麓（福岡，標高 $400 \sim 700 \mathrm{~m}, 1974$ 年 8 月 14日，8 箇所）

2. 多良岳山麓（佐賀，標高 $300 \sim 500 \mathrm{~m}, 1974$ 年 8 月 16日，6 箇所）

3. 西彼杵半島（長崎，標高 $20 \sim 100 \mathrm{~m}, 1974$ 年. 2 月 9 日, 3 筒所)

4. 国東半島抢よび耶馬溪（大分，標高 $20 \sim 500 \mathrm{~m}$, 1974年 8 月13日，9䇢所）

5. 九重半田高原 (大分, 標高 $900 \sim 1,200 \mathrm{~m}, 1974$ 年

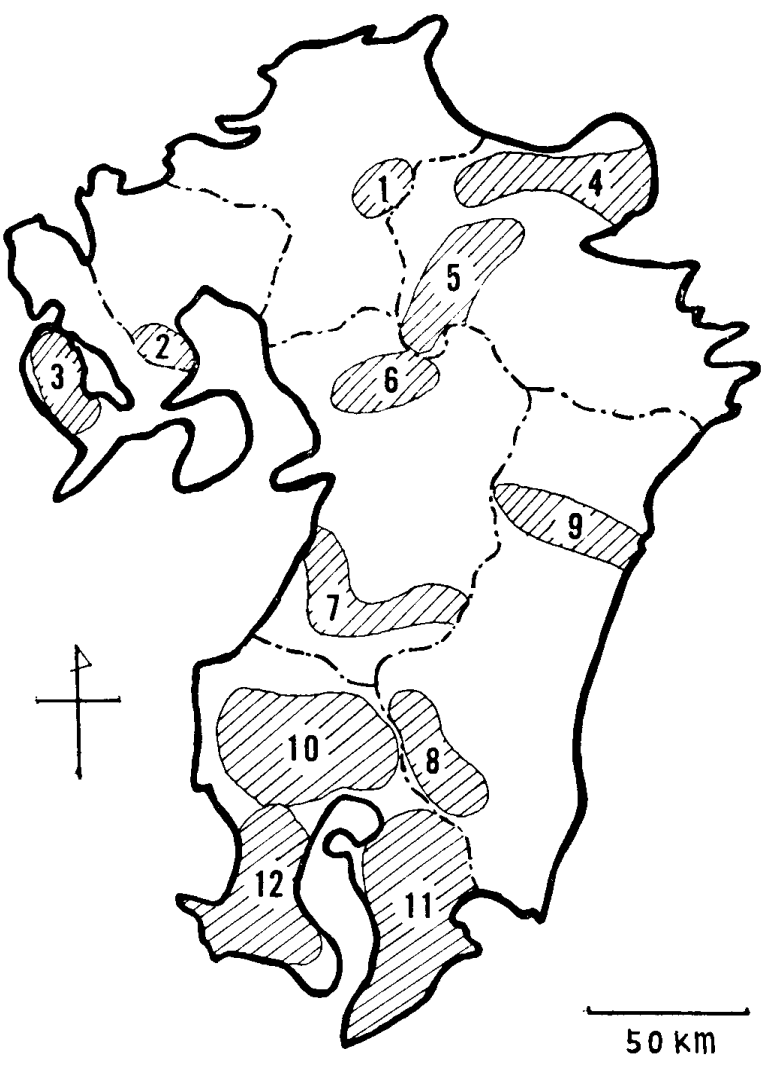

闪1 九州に沶けるブ二约出・蛹の採集場所（番号

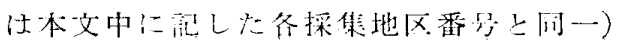


8 月12日，8 筒所)

6. 菊池川上流域抽よび阿蘇外輪山山麓（熊本，標高 $200 \sim 1,000 \mathrm{~m}, 1973$ 年 4 月30日，1974年 8 月 10 ・ 18日，1974年 9 月 11 日，13箇所）

7. 球磨川流域（熊本，標高200 900m, 1974年 8 月 8 日，13䇫所）

8. 関之尾およびえびの高原（宮崎，標高500～1,000 $\mathrm{m} ， 1971$ 年 9 月 15 日，1974年 9 月 14 日， 3 箅所）

9. 耳川流域(宮崎, 標高 $20 \sim 1,000 \mathrm{~m}, 1973$ 年 5 月 $3 \sim$ 5 日，14箇所）

10. 北薩地区（鹿児島，標高10～600m，1971年10月 $2 \sim 5$ 日，16䈏所）

11. 大隅半島, 高隅山山麓（鹿児島，標高10７00m, 1971年10月 $6 \cdot 7$ 日，1972年 5 月 4 日，1974年 8 月 2 日，24籄所）

12. 㬄摩半島 (鹿児島, 標高10 300m, 1971年 4 月21・ 22日，1974年 $2 \cdot 4 \cdot 7 \cdot 8$ 月，24䇢所）

\section{2. 方 法}

各採集場所の水系において水中植物やその他の基物に 付着する幼虫および蛹を，基物とともに（岩・石に付着 する場合はピンセットで，はがした幼虫，蛹のみ）採取 し，ビニール袋へ入れ，研究室へ持ち帰った後 $70 \%$ アル コールの液浸標本とし後日の検鏡に供した。蛹の一部は 個別にポリエチレン試験管に入れ羽化成虫を得た。種名 は日本衛生動物学会蛹研究班編の日本産ブユ科の種目録 （1974）に基うきき，種の同定には衛生動物検査指針 (1971) の検索表に従った.また必要に応じて[Bentinck](1955)， 緒方ら (1956)，および折井ら（1969）の検索表も参照し た.

\section{調查成績ならびに考察}

\section{1. 種類相}

九州各県において行った採集の結果，ブユ幼虫 2,759 個体および蛹2,072個体，合計4,831個体を得た。これら を同定し，表 1 のように Simulium 属の 6 亜属（Eusimulium, Gomphostilbia, Wilhelmia, Odagmia, Gnus および Simulium) に属する18種類と 1 亜種の計19種を 得た. このうち, S. (E.) aureohirtum, S. (E.) sasai, S. (E.) subcostatum koshikiense, S. (E.) sp., S. (Go.) ogatai および S. (G.) daisense の 6 種は九州産未記録 種であった. この結果，表 2 に示すように九州に分布 するブユは既知の 19 種に加え， 2 属 (Prosimulium， Simulium) 25種（1覀種を含む）となった。

動物地理学的には九州は旧北区に属し，しかもその南 縁に位置しているが，渡瀬線を境界として東洋区にはい
表 1 九州に打けるブユ科幼虫・蛹の採集成績

\begin{tabular}{|c|c|c|c|c|}
\hline 名 & $\begin{array}{l}\text { 採集 } \\
\text { 数 }\end{array}$ & $(\%)$ & $\begin{array}{l}\text { 蛹 } \\
\text { 個体数 }\end{array}$ & $\begin{array}{l}\text { 幼虫 } \\
\text { 個体数 }\end{array}$ \\
\hline \multicolumn{5}{|l|}{ Simulium (Eusimulium) } \\
\hline aureohirtum* & 10 & $(6.5)$ & 35 & 49 \\
\hline mie & 12 & $(7.7)$ & 12 & 10 \\
\hline sasai & 2 & $(1.3)$ & 16 & 17 \\
\hline uchidai & 67 & $(43.8)$ & 291 & 408 \\
\hline subcostatum koshikiense & $e^{*} 2$ & $(1.3)$ & 4 & 2 \\
\hline sp.* & 2 & $(1.3)$ & 3 & 16 \\
\hline \multicolumn{5}{|l|}{ Simulium (Gomphostilbia) } \\
\hline ogatai* & 8 & $(5.2)$ & 8 & 10 \\
\hline shogakii & 11 & $(7.2)$ & 105 & 39 \\
\hline \multicolumn{5}{|l|}{ Simulium (Wilhelmia) } \\
\hline takahasii & 3 & $(2.0)$ & 46 & 33 \\
\hline \multicolumn{5}{|l|}{ Simulium (Odagmia) } \\
\hline aokii & 40 & $(26.1)$ & 291 & 417 \\
\hline \multicolumn{5}{|l|}{ Simulium (Gnus) } \\
\hline bidentatum & 66 & $(43.1)$ & 598 & 623 \\
\hline nacojapi & 6 & $(3.9)$ & 19 & 19 \\
\hline daisense* & 2 & $(1.3)$ & 2 & 1 \\
\hline \multicolumn{5}{|l|}{ Simulium (Simulium) } \\
\hline arakawae & 56 & $(36.6)$ & 317 & 436 \\
\hline japoicum & 39 & $(25.5)$ & 114 & 280 \\
\hline kawamurae & 3 & $(2.0)$ & 5 & 0 \\
\hline nikkoense & 3 & $(2.0)$ & 15 & 49 \\
\hline quinquestriatum & 41 & $(26.8)$ & 115 & 197 \\
\hline rufibasis & 29 & $(19.0)$ & 76 & 151 \\
\hline 計 & 144 & & 2072 & 2759 \\
\hline
\end{tabular}

*九州からの初記録種

る南西諸島の動植物相とは，かなり異なることが認めら れている.ブユ相についてみると，九州の 25 種および南 西諸島の既知18種のうち11種が共通種で両地域間の種類 似度指数 (Jacard's index) は 52.4 となり，九州本州間 の種類似度指数 $218(24 /(10+1) \times 100)$ に比べかなり少な い值となり，両地域のブユ相に差違が存在することがう かがえる。ささらに南西諸島を，(1)渡瀬線以北の大隅およ

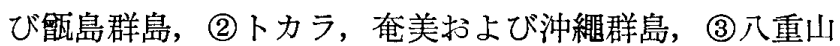
群島の 3 地域に分けて九州との共通種をみると, (1)で11 種のらち10種, (2)で 8 種のうち 5 種, (3)で 4 種のうち 1 種となる.これを九州との種類似度指数でみると(1) 62.5 , (2)20.0, (3)3.7となり, 九州から南下する程ブユ相の違 いが大きくなる様相がらかがえる。すなわち，九州本土 のブュ相は，渡瀬線を境にしてこれより北の島々のブュ 相とはほとんど変わらないが, 一方, 渡瀬線以南のいわ ゆる東洋区に属する奄美, 沖繩および八重山群島のブュ 相とはかなり異なっているといえよう。 
表 2 九州産ブュ科各種類の各県別分布

\begin{tabular}{|c|c|c|c|c|c|c|c|}
\hline \multirow{2}{*}{ 種 } & \multicolumn{4}{|c|}{ 県 } & 名 & \multirow[b]{2}{*}{ 宮 崎 } & \multirow[b]{2}{*}{ 鹿児身 } \\
\hline & 福 岡 & 長 崎 & 佳＼cjkstart賀 & 大 分 & 熊 本 & & \\
\hline \multicolumn{8}{|l|}{ Prosimulium (Prosimulium) } \\
\hline yezoense & + & & & & & & \\
\hline hirtipes (?) & + & & & & & & \\
\hline \multicolumn{8}{|l|}{ Simulium (Eusimulium) } \\
\hline aureohirtum & & & & & & & $(+)$ \\
\hline mie & & + & $(+)$ & $(+)$ & & $(+)$ & $(+)$ \\
\hline sasai & & & & & & & $(+)$ \\
\hline uchidai & $+(+)$ & $+(+)$ & $(+)$ & $(+)$ & $(+)$ & $+(+)$ & $(+)$ \\
\hline subcostatum & + & & & & & & \\
\hline subcostatum koshikiense & & & & & $(+)$ & & $(+)$ \\
\hline sp. & $(+)$ & & & $(t)$ & & & \\
\hline \multicolumn{8}{|l|}{ Simulium (Gomphostilbia) } \\
\hline omutaense & + & & & & & & \\
\hline ogatai & & & & & & $(+)$ & $(+)$ \\
\hline shogakii & $(+)$ & & & & $(+)$ & + & $(+)$ \\
\hline \multicolumn{8}{|l|}{ Simulium (Wilhelmia) } \\
\hline takahasii & & + & & $(+)$ & $+(+)$ & + & \\
\hline \multicolumn{8}{|l|}{ Simulium (Odagmia) } \\
\hline aokii & $+(+)$ & $+(+)$ & $(+)$ & $+(+)$ & $+(+)$ & $+(+)$ & $+(+)$ \\
\hline \multicolumn{8}{|l|}{ Simulium (Gnus) } \\
\hline bidentatum & $+(+)$ & $+(+)$ & $(+)$ & $+(+)$ & $+(+)$ & $+(+)$ & $+(+)$ \\
\hline nacojapi & + & + & $(+)$ & + & $(+)$ & & $+(t)$ \\
\hline malyshevi & & + & & & & & \\
\hline daisense & & & & & & & $(+)$ \\
\hline \multicolumn{8}{|l|}{ Simlium (Simulium) } \\
\hline arakawae & $+(+)$ & $+(+)$ & $(+)$ & $+(+)$ & $+(+)$ & $+(+)$ & $+(+)$ \\
\hline japonicum & $+(+)$ & & & $(+)$ & $+(+)$ & $(+)$ & $+(+)$ \\
\hline kareamurae & & & & & $(+)$ & $+(+)$ & \\
\hline nikkoense & & $(t)$ & & + & $(+)$ & & $(+)$ \\
\hline quinquestriatum & & $+(+)$ & $(+)$ & $+(+)$ & $+(+)$ & $(+)$ & $(+)$ \\
\hline rufibasis & $+(+)$ & & & $(+)$ & $(+)$ & $(+)$ & $(t)$ \\
\hline suzukii & + & & & & & + & \\
\hline
\end{tabular}

十 : [Bentinck] (1955) および緒方ら（1956）による既知分布種

（十：著者らの調查で分布が確認または追加記録された種

各県別のブユ相の分布を表 2 に示した。 福岡県では S. (E.) sp. とS. (Go.) shogakii の 2 種，長崎県では $S$. (S.) nikkoense の 1 種, 佐賀県では $S$. (E.) mie, $S$. (E.) uchidai, S. (O.) aokii, S. (G.) bidentatum, $S$. (G.) nacojapi, $S .(S$.$) arakawae および S .(S$.$) quin-$ questriatum の 7 種, 大分県では $S$. (E.) mie, $S$. (E.) uchidai, S. (E.) sp., S. (W.) takahasii, S. (S.) japonicum ならびに $S .(S$.$) rufibasis の 6$ 種, 態本県から S. (E.) sub. koshikiense, S. (Go.) shogakii, S. (G.) nacojapi, $S$. (E.) uchidai, $S$. (S.) kawamurae, $S$. (S.) nikkoense および $S$. (S.) rufibasis の 7 種, 宮崎県から $S$. (E.) mie, S. (Go.) ogatai, $S$. (S.) japonicum, $S$. $(S$.$) quinquestriatum ならびに S$. (S.) rufibasis の 5 種, 鹿児島県加 $S .(E$.$) aureohirtum, S .(E$.$) mie,$ $S$. (E.) sasai, S. (E.) uchidai, $S$. (E.) sub. koshikiense, S. (Go.) ogatai, S. (Go.) shogakii, S. (G.) daisense, $S .(S$.$) nikkoense, S .(S$.$) quinquestriatum$ および $S$. (S.) rufibasis の11種を各県下のブユの新分布 種として追加した．表 1 に示すように，採集数が総数の 約 $20 \%$ 以上值を示す 7 種は, 九州北部の福岡から南部 
の鹿児島県までほとんどの県下で見出されたままた（ほ とんどの種が九州の中央部を南北に走る九州山脈（標高 約 $1,000 \sim 1,700 \mathrm{~m})$ によって分隔された東西両地域から も採集されたことから，九州内の地形的障壁，または気 候的違いなどでは，ブユ相の分化はみられないように思 われる。 したがって各県下のブユ相は今後採集を十分行 えばほぼ類似の構成になると思われる。

\section{2. 種構成比ならびに採集頻度からみた九州における ブユの普通種}

ブユ幼虫・蛹は種毎に棲息水系に選択性を示し，各河 川型での棲分けや季節によるブユ幼虫・蛹の遷移がみら れることが報告されている（可児，1952；正垣・清水， 1956 ; 緒方・福井, 1957 ; 折井ら，1964）.

今回は九州といら広い地域での種類相および分布状況 の把握を目的とした採集であり，方法も定量採集ではな かったので, 各採集地区および採集時期,さらに各河川型 別の種の棲分けや優勢度に関しては詳細な観察および考 察は行わなかった.ここでは,九州においてどの種が最も 普通にみられるものかを知るためにのみ各採集地区別， さらに採集地区 $6 ・ 10 \cdot 11$ 扝よび12では，採集を行った 月別に幼虫・蛹の合計個体数からなる種構成比を求め, 各種の優勢度をみてみた(表 3 ).その結果, 春季の $4 \cdot 5$ 月に採集老行った 4 地区(地区番号 $6 \cdot 10 \cdot 11 \cdot 13$ )に掠 ける種構成比では，S. (G.) bidentatum が 3 地区 (33.7 $\%, 34.2 \%, 67.7 \%)$ で高い優勢度を示した。 また $S$. (O.) aokii, S. (S.) rufibasis の 2 種は 2 地区において, $S .(S$.$) arakareae, S .(E$.$) uchidai, S .(S$.$) japonicum$ の 3 種は㧈の扔の 1 地区で優勢度 $10 \%$ 以上であった。夏 季の 7 ・8 月に採集を行った10地区における種構成比で は，10\%以上の優勢度を示したのは，S. (S.) arakawae (7 地区) , S. (G.) bidentatum 抢よび $S$. (S.) quinquestriatum (各 5 地区), $S .(O$.$) aokii (4 地区), S. (E.)$ uchidai ( 3 地区), S. (Go.) shogakii, S. (W.) takahasii 拈よび $S$. (E.) aureohirtum (各 1 地区) の 8 種 であった。秋季の 9 ・10月に採集を行った地区 6 ・8・ 10・11に扔いては， $S .(S$.$) arakawae が3 地区でおの$ おの $15.5 \%, 20.7 \%, 32.0 \%$ を占め, 次いで $S .(G$. bidentatum, S. (S.) japonicum が 2 地区でおのおの $16.9 \% ， 22.2 \%$ および16.7\%，24.3\% と優勢であった。 また, S.(O.) aokii, S.(S.) rufibasis, S.(E.) uchidai, $S .(S$.$) quinquestriatum, S .(E$.$) aureohirtum 05$ 種 は 1 地区で $10 \%$ 以上の優勢度を示した。 冬季の 2 月に 採集を行った 2 地区（地区番号 3 ・12）では， $S .(E$. uchidai が23.5\%, 38.1\%，S. (S.) japonicum が26.5 $\% ， 19.8 \%$ と両地区に㧍いて優勢種であった． $S .(S$. quinquestriatum および $S .(S$.$) rufibasis の 2$ 種は 1
地区で10\%以上の優勢度を示した，これらの結果から， 地区別㧍上び季節別の優勢種の構成㧍よび割合は幾分異 なるにしても，S. (G.) bidentatum, $S$. (S.) arakawae, S. (O.) aokii, S. (E.) uchidai, S. (S.) japonicum, $S .(S$.$) quinquestriatum および S .(S$.$) rufibasis 97$ 種のうちの数種の組み合わせによって優勢種が構成され ていることがうかがえる。全採集地区を一括し，総個体 数に対する各種の個体数の割合で構成比をみると, $S$. (G.) bidentatum が $25.3 \%$ で最優勢種となり，次いで $S .(S$.$) arakawae, S .(O$.$) aokii, S .(E$.$) uchidai \Phi$ 順序で優勢であった。この 4 種によって総個体数の $70 \%$ が占められた。 さらに，S. (S.) japonicum, S. (S.) quinquestriatum および $S$. (S.) rufibasis の 3 種を加 えると全体の $90 \%$ が占められた．また，表 1 に示した総 採集数に対する各種の採集数の割合でも個体数による構 成比の優勢の順位とほぼ平行な結果が得られることから 上記 7 種が九州に扔ける普通種と思われる。

\section{3. 地理的分布}

今回の九州に扔ける分布調查の結果と九州の北東打よ び南に隣接する本州掠よび南西諸島のブבに関する知見 をもとに九州産ブユの地理的分布域をまとめてみた。 九州産 25 種のうち10種が本州䇽よび南西諸島両域に分布 がみられる。このらち 7 種が本州および九州に広く分布 し，南西諸島に分布の南限がみられるものである。(㼥 島まで, $S .(O$.$) aokii; 種子島・屋久島まで, S .(E$. uchidai, $S .(S$.$) arakawae; 徳之島まで, S .(G$.$) bi-$ dentatum; 沖繩本島まで, $S .(E$.$) mie, S .(S$.$) japo-$ nicum, S. (S.) suzukii) (Takaoka, 1976). 他の 3 種, すなわち, $S$. (E.) aureohirtum, $S .(S$.$) quinquestri-$ atum, $S$. (S.) rufibasis は主に東洋区に分布がみられ南 西諸島を通過し，さらに九州以北まで分布の拡がりが認 められている。

次に本州，九州両域に分布し南西諸島のいずれの島か らも記録されていない13種のうち,S.(E.) sasai,S. (Go.) shogakii, S. (Go.) ogatai, S. (G.) nacojapi, S. (G.) daisense および $S$. (S.) nikkoense の 7 種は九州南端の 鹿児島県本土を分布の南限としているものと思われる。 残りの 6 種については今回採集されなかったか，または 採集されても採集数が少なかったといらことと, 最も調 查数が多かった鹿児島県下で採集されていないという理 由から，恐らく分布の南限を鹿児島県の以北に有すると 思われるが結論は出せなかった，ただ Prosimulium 属 の 2 種は北方系の山地性の種類であるため九州では北部 の山地に限って分布するものと思われる. 本州に分布す る種のうち Twinna japonensis, P. kanii, P. jezonicum, Cnephia mutata, S. (E.) kobayashii, S. (E.) konoi, 
Vol. 28 No. 41977 年

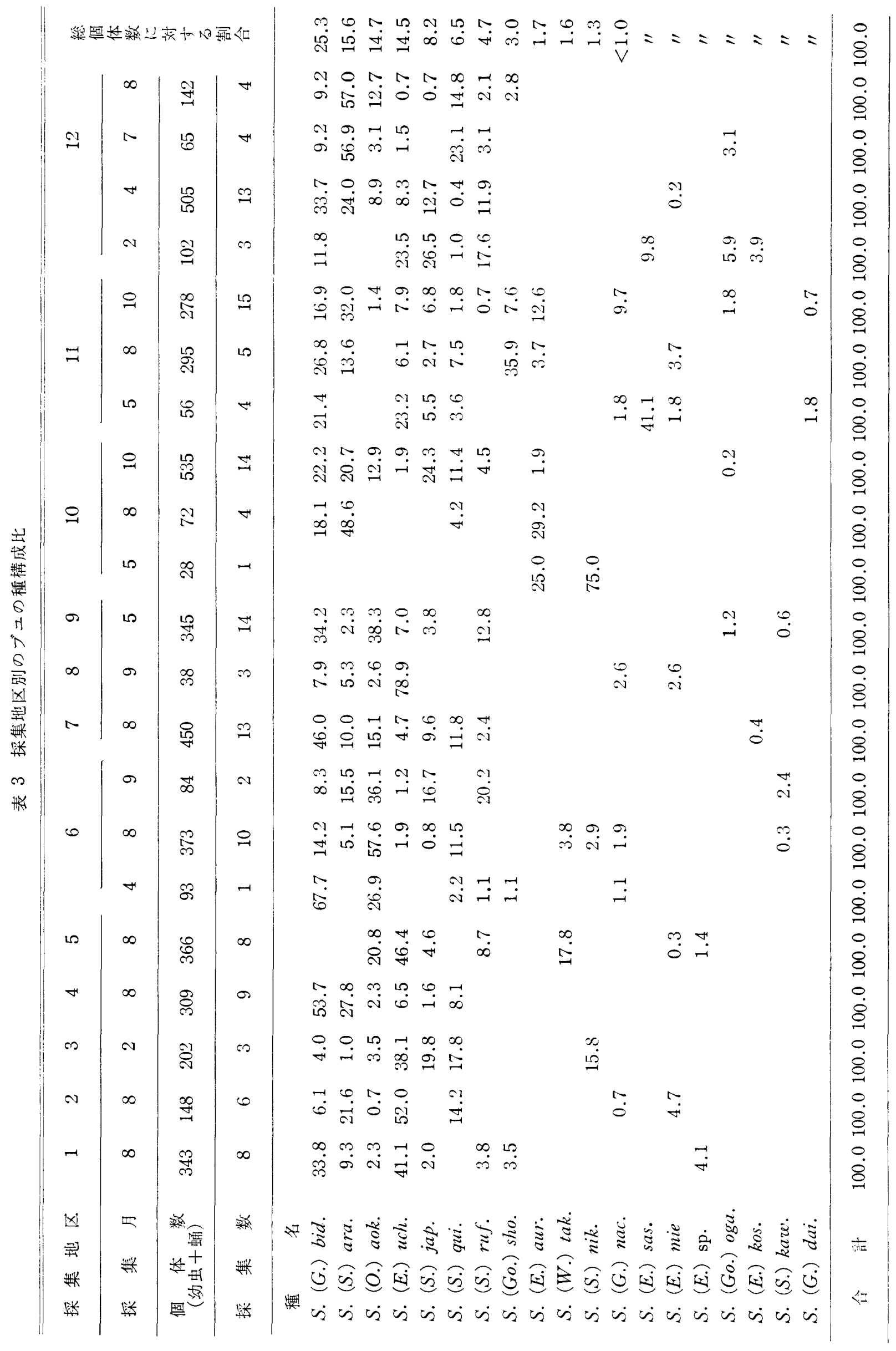


S. (Go.) yamayaense, S. (G.) kisoense, S. (O.) iwa tense, S. (Boophthora) yonagoense の10種は[Bentinck] （1955）および緒方ら（1956）による調查でも，また今 回の調査でも得られなかった。これらの10種はいずれも 北方系種であることから，今回の採集調査が時期的にも 限られたものであったが，北区の南縁に位置する九州ま では分布していないと思われる。

\section{4. 重直分布}

今回採集された19種について垂直分布をみると， $S$. (E.) uchidai, S. (S.) rufibasis, S. (S.) japonicum, S. (O.) aokii, (以上 $1,200 \mathrm{~m}$ まで), S. (G.) bidentatum, S. (E.) mie（以上 $1,000 \mathrm{~m}$ まで）の 6 種は低地か ら高地までの広い範囲にわたり分布がみられた．S. $(E$. sp. は中腹 $(450 \mathrm{~m})$ および高地 $(1,200 \mathrm{~m})$ でまれにみら れた. 一方, S. (Go.) shogakii, S. (S.) arakawae $(700 \mathrm{~m}$ まで), S. (W.) takahasii, S. (S.) quinquestriatum, S. (G.) nacojapi (500m まで) の 5 種は低地 より中腹にかけて分布していた。他の種は採集数は少な かったが，いずれも $200 \mathrm{~m}$ 以下の低地に分布が限られて いた. 前述の九州に扔ける普通種 7 種は垂直分布におい ても広い分布域を有していることが認められた。ブユの 垂值分布に関しては正垣・清水（1956）の長野県下に おける観察記録および斉藤・梶原（1975）による山梨県 における冬期の報告がある．正垣・清水によると九州と 共通種のうち $S .(S$.$) arakawae は標高 1,300 \mathrm{~m}, S .(S$. japonicum は1,300 1,600m,S. (S.) kawamurae は 1,020m の高地加らも記録されており，九州でのこれら 種よりさらに広い分布範囲が観察されている。山梨県下 においては, 九州での普通種 7 種のうち山梨で採集され ていない S. (S.) quinquestriatum 以外はどの種も高低 を問わず広い分布範囲を示すという今回の調査結果とほ ぼ同様の結果が報告されている.この他，S. (E.) mie， S. (S.) kawamurae の 2 種は山梨県下ではいずれも中 腹から高地にかけて限られた分布を示すのに対して，九 州では前者が低地から高地まで広い範囲で, また, 後者 は低地だけに分布するなど垂直分布範囲の一致しない種 もみられた，広い地理分布を有する種では地域特有の気 象条件, 棲息環境要因, 種別の選好河川の有無などによ って，種類によっては，垂直分布の範囲にも異なった傾 向がみられるものと思われる.

\section{5. 未記録種について}

S. (E.) aureohirtum一一本来, 東洋区系の種類であ る本種は，東南アジアに広い分布域を有し，旧北区に含 まれる本州でも瀬戸内海の下蒲刈島およびその対岸地区 （緒方ら，1956)，京都ならびに千葉([Bentinck〕，1955)， 鳥取（岡本，1958）から記録されている。をた，九州の
南に連なる南西諸島では流水系を有するほとんどの島に 分布している (Takaoka，1976) ことから，本種の九州 における分布は予期されたものであった，九州では鹿児 島県各地の低地水田地带のきわめて小さい流れから採集 された. 採集記録 : 出水郡野田鄉, 出水市宇都野, 川内 市中原，および草道（採集日；1971年10月 5 日），鹿児 島市五ケ別隹（1970 年 9 月15日），鹿児島市宮脇（1972 年 8 月 24 日), 姶良郡蒲生 (1972年 5 月 28 日), 揖宿郡喜 入 $(1973$ 年 2 月 16 日), 肝属郡垂水市高城（1972 年 8 月 20 日)，肝属郡佐多（1971年10月 6 日）。

S. (E.) sasai一一本種は本州の石川県および長野県の 高地 (標高約 $1,300 \mathrm{~m}$ ) から [Bentinck](1955) により 報告されたが，九州では鹿児島県大隅半島と薩摩半島か ら，いずれもS. (E.) aureohirtum と同様低地水田地帯 の細水路から採集された，発生量は少ない，採集記録： 肝属郡垂水市高城 (1971年 5 月 3 - 15日), 鹿児島市伊作 峠三取合 (1973年 3 月 9 日).

S. (E.) sub. koshikiense一一本種は Takaoka(1976) により下酤島から採集され，北海道を基産地とする $S$. (E.) subcostatum と 雌の 額面 (Frons) の形，小腮垻 (Maxillary palp) の小襄 (Vesicle) の大きさ等に差が 認められることから亜種として記載された．今回，態本 紧球磨郡横谷 (1974年 8 月 8 日)，および鹿児島伊作峠三 取合（1973年 3 月10日）溪流で採集した幼虫，蛹および 蛹より羽化させた雌成虫の形態が $S$. (E.) sub. koshikiense の記載と一致したので本亜種と同定した．緒方ら (1956)，および[Bentinck](1955) は福岡県からS.(E.) subcostatum を記録しているが，筆者らはこれら標本を 見る機会がなく，また同県下よりこれに相当する標本を 採集し得なかったために，本亜種との比較は行っていな い.

S. (E.) sp.——本種は vernum グループに属し, 幼 虫の頭蓋板腹面の cleft の形, およびその深さが浅く bridge の約半分の長さしかないことから本グループの他種 と区別される，本邦では大西ら（1971）によって京都の 一乗寺に㧍いて上述の特徴を有する種類が $E$. sp.-3 と して発表された，その共同発表者の 1 人，上本騏一博士 より $E . \mathrm{sp} .-3$ の標本を供与いただき九州産標本と比較 したところほぼ一致した．種名が未だ与えられていない ため，ここでは，S. (E.) sp.とした. 採集記録：大分 覍九重高原（標高 $1,200 \mathrm{~m}$ ) 低灌木林内の細流（源流型） （1974年 9 月11日）および福岡県朝倉郡小石原（標高450 $\mathrm{m})$ の川幅約 $1 \mathrm{~m}$ の溪流より（1974年 8 月14日）採集.

S. (Go.) ogatai一一本種は京都から[Bentinck] (1955) により S. sp. J-13として報告された種であるが，九州 では宮崎と鹿児島両県の低地の小流から採集された，採 
集記録：宫崎県田代 (1974年5月 3 日), 鹿児島県出水郡 柳野(1971年10月 5 日), 姶良郡平原(1971年10月 2 日), 姶良郡蒲生 (1974年 8 月 26 日), 鹿児島市谷山（1972年 4 月27日), 鹿览島市永田 (1972年 7 月 22 日), 鹿览島市伊 作趾三取合 (1974年: 7 月24日)，鹿览島市五ケ別府 (1974 年 7 月 15 日).

S. (G.) daisense一一庇児島県肝属郡吾平山陵（1971 年10月 6 日，1972年 5 月12日）でわずか蛹 2 個体, 幼虫 1 個体を採集したのみであった，蛹1個体は羽化直前の 雄成虫を内包していたので, 雄の外部生殖器については 観察出来た，蛹の呼吸系は16本に分岐し，各枝は太く, 薄膜状を呈すること, さらに雄の外部生殖器の形態等の 特徴が高橋（1971）が改めて発表した S. (G.) daisense の特徴と一致するので同種と同定した。 九州からは [Bentinck]（1955）により本種と類似のS. (G.) malyshevi が長崎から報告されているが，呼吸系および外 部生殖器の形態で区別される.

\section{要 約}

1）九州各県の144箅所においてブユ幼虫・蛹の採集 を行った結果，1属19種（1韭種を含む）が得られた.

2) このらち, S. (E.) aureohirtum, S. (E.) sasai, S. (E.) sub. koshikiense, S. (E.) sp., S. (Go.) ogatai, および S. (G.) daisense の 6 種は九州より初めて記録 された.

3）総採集個体数および総採集数に対する各種の個体 数および採集数の割合より九州の全県下に分布がみられ た S. (G.) bidentatum, S.(O.) aokii, S. (S.) arakawae, S. (E.) uchidai の 4 種, およびS. (S.) japonicum, S. (S.) quinquestriatum, S. (S.) rufibasis の 3 種を加え た 7 種が九州における普通種と思われた.

4）九州産ブニの地理的分布（特に南限に関して）お よび垂㨁分布に関して論述された.

稿を終るにあたり御指導を得た鹿児島大学医学部任藤 湊夫教授, 種々の御教示をいただき,また貴重な標本を 御提供下さった自衛隊衛生学校高橋弘博上, 滋賀医科大 学上本騏一博上に臮く感謝する。

\section{文献}

朝比永正二郎編 (1971)：衛生動物検查指針。日本環 境衛生センター，川崎，300pp.

[Bentinck] (1955) : The black flies of Japan and Korea (Diptera: Simuliidae) $406 \mathrm{Medical} \mathrm{Ge-}$ neral Laboratory U. S. Army, 23pp, figs. 33. 可㫛藤吉 (1952)：渓流昆虫の生態学的研究. 木暨王 滰川昆虫誌, 木賏教育会, $216 \mathrm{pp}$.

口本衛生動物学丟ブユ研究班編(1974)：日本産ブユ
科の種目録. 衛生動物, 25(2): 191-193.

Ogata, K. and M. Sasa (1954) : Taxonomic notes on Simuliidae or black flies of Japan, with special references on the subgenera Eusimulium Roubaud and Nevermannia Enderlein (Diptera). Jap. J. Exp. Med., 24(5) : 325-333.

緹方一喜, 佳々学, 鈴木猛 (1956) : ブュとその距除. DDT 協会，東京，162pp.

緒方一喜，福井正信 (1957)：高尾山一水系に於ける ブュ幼虫・蛹の群集構造とその季節的遷移につい 下. 衛生動物, 8(3) : 127-135.

岡本詢 (1958)：山陰地方に於ける蚋の種類と分椎に 関寸る研究。米子医学雑誌，9(4)：566-579.

大西修，上本騏一，折井健 (1971)：本邦産ブユ, Eusimulium 属の未記録種についてII第23回日 本衛生動物学会大会講演要旨, p. 77 .

折井健，北村茂，上本騏一，石野卯芦，熊澤誠義 (1964)：京都市北郊に抬けるブュの研究 V.ブニ 幼虫・蛹の分布と季節消長。衛生害虫, $8(1 \cdot 2)$ : 36-52.

折井健，上本騏一，大西修 (1969)：日本座ブユ幼出 の検索について，衛生害虫，13(1):1-13.

斎藤一三，梶原德明 (1975)：山梨県汇打ける各期の ブュ採集成績. 衛生動物, 26(1) : 55-60.

Shiraki, T. (1935) : Simuliidae of the Japanese Empire. Mem. Fac. Sci. Agr. Taihoku Imp. Univ., $16: 1-90$.

正垣幸男, 清水常夫 (1956)：日本産ブユの生態学的 研究 (Simuliidae, Diptera). I . 長野噁菅平地方 のブュ相. 動物学雑誌, $65(2): 15-20$.

高橋弘(1971) : Nevermannia konoi Takahasi 抢上 び Gnus daisenensis Takahasi について (蚋科). 第23回日本衛生動物学会大会講演要旨, p. 80 .

Takaoka, H. (1976) : Studies on black-fies of the Nansei Islands, Japan (Simuliidae; Diptera) I. On six species of the subgenus Eusimulium Roubaud, with the descriptions of Simulium (E.) satsumense sp. nov. and $S$. (E.) subcostatum koshikiense ssp. nov. Jap. J. Sanit. Zool., $27(2)$ : 163-180

\section{Summary}

Investigations were carried out on the fauna and distributions of black-flies in Kyushu in 19711974. A total of 2,072 pupae and 2,759 larvae were collected from 144 sites in 12 districts. Eighteen species and 1 subspecies were found, of which Simulium (Eusimulium) aureohirtum, $S$. (E.) sasai, $S$. (E.) subcostatum koshikiense, $S$. (E.) sp., S. (Gomphostilbia) ogatai and S. (Gnus) daisense were recorded for the first time from Kyushu. This brought the total number of Simuliidae in Kyushu to 25. The most abundant and widely distributed species are: $S$. (G.) bidentatum, $S$. (Simulium) arakawae, S. (Odagmia) aokii, S. (E.) uchidai, making up about $70 \%$ of the total number of specimens collected.

Notes on geographical and vertical distributions of 19 taxa of black-flies in Kyushu were given. 